doi: $10.19090 / \mathrm{i} .2017 .28 .7-28$

UDC: $902 / 904(32)$

\author{
UROŠ MATIĆ \\ University of Münster \\ urosmatic@uni-muenster.de
}

\title{
SCORCHED EARTH: VIOLENCE AND LANDSCAPE IN NEW KINGDOM EGYPTIAN REPRESENTATIONS OF WAR
}

\begin{abstract}
Death and destruction of peoples and lands are the reality of war. Since the Old Kingdom the destruction of enemy landscape is attested in Egyptian written sources and the number of attestations increases in the following periods, culminating in the New Kingdom. This is also the period when the first visual attestations of enemy landscape destruction appear. In this paper I will explore the actors, targets and acts concerning violence against enemy landscapes together with the use of landscape elements as metaphors for the violent treatments of enemies during the New Kingdom. The study shows that there are differences in representations of treatments of SyroPalestinian and Nubian landscapes, which could be related to the reality of war itself, as monumental enemy fortresses did not exist in Upper Nubia, at least not on the same scale as in Syria-Palestine. This real difference went hand in hand with the ancient Egyptian construction of the Other as unsettled. Thus, urban landscapes of Syria-Palestine are objects of violence in the visual record where they are reduced to unsettled landscapes through destruction and desolation. It is also shown that this reality of war is additionally framed through Egyptian rules of decorum ascribing most of the destructions of landscape to the king and only some to the soldiers.
\end{abstract}

Keywords: violence, war, landscape, New Kingdom, Egypt, Syria-Palestine, Nubia.

\section{Introduction}

$\mathrm{T}$ This paper explores the complex relation between violence and landscape in New Kingdom Egyptian written and visual representations of war. I understand violence most broadly as "the intentional use of physical force or power, threatened or actual, against oneself, another person, or against a group or community, which either results in or has a high likelihood of resulting in injury, death, psychological harm, maldevelopment, or deprivation" and landscape as "physical and visual form of the earth as an environment and as a setting in which locales occur and in dialectical relation to which meanings are

\footnotetext{
${ }^{1}$ Krug et al. 2002.
} 
created, reproduced and transformed". ${ }^{2}$ Landscape is both a medium for and an outcome of action. ${ }^{3}$ Thus, violence against landscape is the use of physical force to harm, destroy or negatively change physical and visual forms of environment by causing injury, maldevelopment and deprivation among its inhabitants, but also changes in meanings associated to it. Although landscape is shaped by men and vice versa and can therefore include creations of men such as architecture (houses, dwellings, forts etc.), in this paper I will not deal with the motif of the storming of an enemy fort in ancient Egyptian art. This has been the topic of some other studies and an extensive collection of ancient Egyptian representations of enemy fortresses was recently discussed too. ${ }^{4}$ In this paper I will refer only to the representations of desolated forts. This is because I am more interested in the relation of this particular motif to other motifs of landscape destruction and desolation than in studying siege of fortresses.

Although this paper primarily deals with New Kingdom sources it must be mentioned that the motif of landscape destruction is attested already in earlier periods of ancient Egyptian history. We find it in the biography of Kaemtjenenet of the $5^{\text {th }}$ dynasty ${ }^{5}$ and the biography of Weni of the $6^{\text {th }}$ dynasty. ${ }^{6}$ The Middle Kingdom attestations are more numerous and include the rock inscription of Antefoker (Žába 73, lines 9-10) ${ }^{7}$, the stela of Mentuhotep from Buhen (Florence $2540 \mathrm{~A}+\mathrm{B}$, line 18) ${ }^{8}$, the great Semna stela (Berlin 1157, lines 15$16)^{9}$ and the Uronarti stela (Khartoum 451, line 12) ${ }^{10}$. The motif is also known during the Second Intermediate Period as in the Second stela of Kamose of the $17^{\text {th }}$ dynasty in the Karnak temple (line 12). ${ }^{11}$ However, the number of attestations is considerably larger in the New Kingdom. This can be on the one hand explained by increased military activities of the Egyptian state in Syria-Palestine and Nubia and on the other hand with an increased role of monumentality in the representation of military exploits with stelas and temples as bearers of written and visual representations of war. It should also not be excluded that the larger number of attestations during the New Kingdom are due to the poor preservation of earlier monuments.

Some of the sources with attestations of violence against foreign landscapes were already analysed by Anthony J. Spalinger (1982), Michael G. Hasel (1998), Georg Meurer (2001), Susanna C. Heinz (2001) and Sydney H. Aufrère (2005), or mentioned in passing by Colleen Manassa (2013). Spalinger dealt with the attestation of the lexeme $j n . t$ "(desert) valley" 12 in New Kingdom documents concluding that the enemies hiding in their valleys was one of the most common expressions of their cowardness. ${ }^{13}$ This observation is in line

\footnotetext{
2 Tilley 1994: 25

${ }^{3}$ Ibid.: 23

${ }^{4}$ Monnier 2014.

${ }^{5}$ Urk. I, 185, 12-186, 6; Strudwick 2005: 283

${ }^{6}$ Urk. I, 103, 6-104, 4; Strudwick 2005: 354.

${ }^{7}$ Žába 1979: 98-109.

${ }^{8}$ Smith 1976: 39-41.

${ }^{9}$ Wreszinski, Ranke und Burchardt 1913: 258

${ }^{10}$ Janssen 1953: 53-54.

${ }^{11}$ Habachi 1972: 36.

${ }^{12} \mathrm{~Wb} 1,93.2-14$.

${ }^{13}$ Spalinger 1982: 52.
} 
with other Middle Kingdom ${ }^{14}$ and New Kingdom motifs of cowardly Nubians, ${ }^{15}$ which will be discussed later in this paper. Hasel only briefly mentions the destruction of crops, orchards and trees ${ }^{16}$ and burning of people and cities. ${ }^{17}$ Meurer does not include all of the known sources in his study and he does not discuss some aspects of violence and landscape such as the use of landscape as a metaphor for the consequence of violent acts or landscape as a setting of violent acts. ${ }^{18}$ Meurer also does not include sources in which violence against enemy bodies is described using landscape metaphors. Heinz discusses the few known visual attestations of the destructions of enemy fortresses, including those in which the fortress is depicted with its entrance destroyed and she describes them as "uninhabited". ${ }^{19}$ Recently a detailed study of ancient Egyptian representations of enemy fortresses has been published by Franck Monnier. ${ }^{20}$ Since the fortresses with the destroyed entrance are also depicted with enemies on the upper levels or falling down from them it cannot be said that they are uninhabited, but rather that storming the gate was a method to allow the Egyptian army to come in, implying the ultimate defeat of the enemy. Therefore, the motif of the demolished gate should be, as Carola Vogel suggested, understood as pars pro toto for the successful conquest of enemy towns. ${ }^{21}$ This is also indicated by the representation of an enemy fort of Tunip depicted on the north wall between the $1^{\text {st }}$ and $2^{\text {nd }}$ pylon of the Medinet Habu temple. Here Egyptian soldiers are storming the gate, climbing ladders to get in, fighting enemies inside the fort itself, but are also accompanied by an Egyptian trumpeter. He is blowing his trumpet in the direction of the pharaoh and his army and is thus giving the signal that the enemy fort has been taken (Fig. 3). Indeed in the corpus studied by Heinz there are depictions in which there are armed Egyptian soldiers in front of the gate. ${ }^{22}$ Therefore, I will not treat the representations of destroyed gates as evidence for desolated and uninhabited fortresses, but only those of unequivocally abandoned fortresses and landscapes (Figs. 1, 2, 3). Aufrère presented the most recent study of ancient Egyptian sources in which the destruction of enemy landscape is mentioned and he compared it to both Assyrian and Old Testament evidence. ${ }^{23} \mathrm{He}$ provided a lexical analysis of the verbs used to denote the destructive acts and the nouns used as objects of destruction. In his study he does not mention some of both textual and iconographic evidence which will be covered here. Aufrère argued that the scorched earth strategy is for the first time denounced as barbarous in Deuteronomy $(20,19-20){ }^{24}$ This clearly indicates that there are different cultural attitudes towards the destruction of enemy landscape ${ }^{25}$ and one ought to consider them in a broader context of the social construction of "us vs. them" and "our land vs. their

\footnotetext{
${ }^{14}$ Fischer-Elfert 2005: 330-331.

${ }^{15}$ Spalinger 2011: 34; Matić 2017a.

${ }^{16}$ Hasel 1998: 75.

${ }^{17}$ Ibid.: 85.

${ }^{18}$ Meurer 2001.

${ }^{19}$ Heinz 2001: 153-154.

${ }^{20}$ Monnier 2014.

${ }^{21}$ Vogel 2010: 316

${ }^{22}$ Heinz 2001: 294.

${ }^{23}$ Aufrère 2005.

${ }^{24}$ Ibid.: 57.

${ }^{25}$ For example see Mesopotamian evidence in which landscape itself can be perceived as an enemy, Galter 2016.
} 
land". Manassa mentioned that the battle reliefs use landscape among other elements to designate the enemies, thus we find deserted fortresses as part of the Libyan campaigns or aquatic settings of the naval battle with the Sea Peoples. ${ }^{26}$ This is an interesting suggestion indeed, however ancient Egyptian representations of different foreign landscapes in relation to the traits of people who inhabit them are beyond the scope of this paper, which deals solely with the destruction of landscape elements. In this paper, following the already proposed suggestions by Hans-Werner Fischer-Elfert and Anthony J. Spalinger, I will among all else argue that landscape was one of the motifs used to indicate the difference between Egyptians and the Others, but also in a way to create a hierarchy of the Others. In line with the question Richard B. Parkinson posed regarding literary representations of landscapes, namely, "what variations and emotions that the ancient texts contained for their original readers have now been lost for us", ${ }^{27}$ this paper explores the possible meaning contents of representation of landscape destruction.

Written and visual attestations of violence against enemy landscapes in the New Kingdom Egypt will be analysed together with those attestations in which landscape and its elements are used to express violence committed against the enemies. This is done in order to gain a more comprehensive insight into the problem. The goal of this study is to investigate which violent acts are committed, which elements of landscape are targeted and if there are differences that can be observed in written and visual attestations. Also, it will be explored if the corpus is showing differences in regards to the regions in question, namely Syria-Palestine, Libya and Nubia. The embeddedness of violence in the Nile valley landscape through triumphal rituals and the use of violence in the integration of Nubia into the sacred landscape of Egypt is covered elsewhere. ${ }^{28}$

\section{Materials and Methods}

This study covers New Kingdom inscriptions from private tombs, royal stelas and temples, but also visual representations of war on temple walls. Landscape as a target of violence was studied in nine written sources with fourteen attestations and three visual sources. As a metaphor for violence, landscape was studied in five written sources (Tables 1, 2; Figs. 1, 2, 3).

This makes a total of nineteen written and three, possibly four, ${ }^{29}$ visual attestations studied in this paper. The earliest is from the reign of Thutmose I and the latest from the reign of Ramesses III. Visual attestations are found only under Ramesses II and Ramesses III.

\footnotetext{
${ }^{26}$ Manassa 2013: 10.

${ }^{27}$ Parkinson 2015: 3 .

${ }^{28}$ Spalinger 2013; Matić 2017a.

${ }^{29}$ This depends on the interpretation of one of the blocks from the temple of Ahmose's date from Abydos. A hand can be seen on the block holding grain. The question is if this action is to be interpreted as violent, namely cutting of the grain, or not. If so, this would be the earliest visual attestations of scorched earth in the New Kingdom and the only known visual attestation of grain cutting, well attested in written sources (Table 1). For the photo and the drawing of the block see Harvey 1998: 535; Spalinger 2005: 20, with courtesy of Stephen P. Harvey.
} 


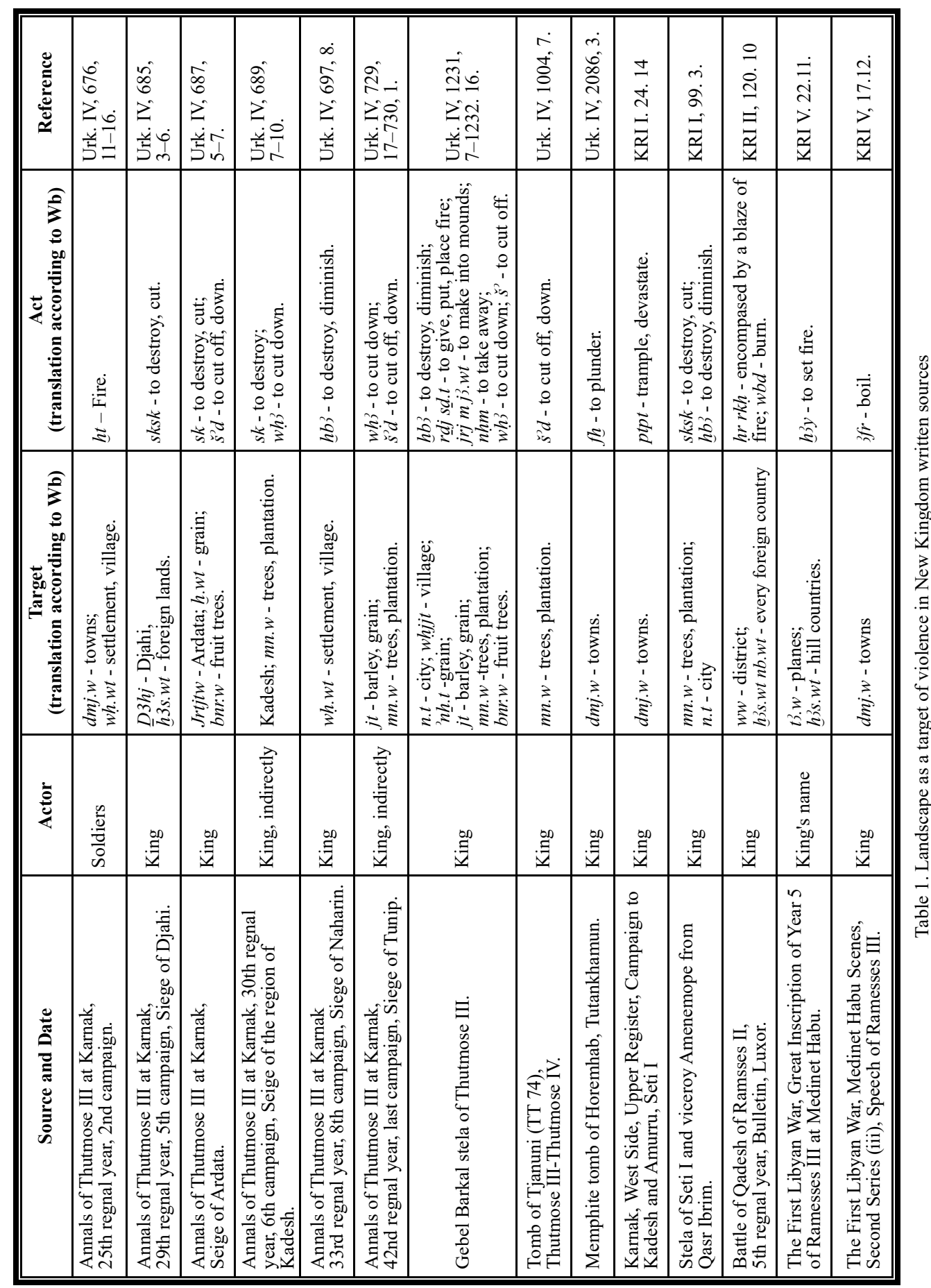




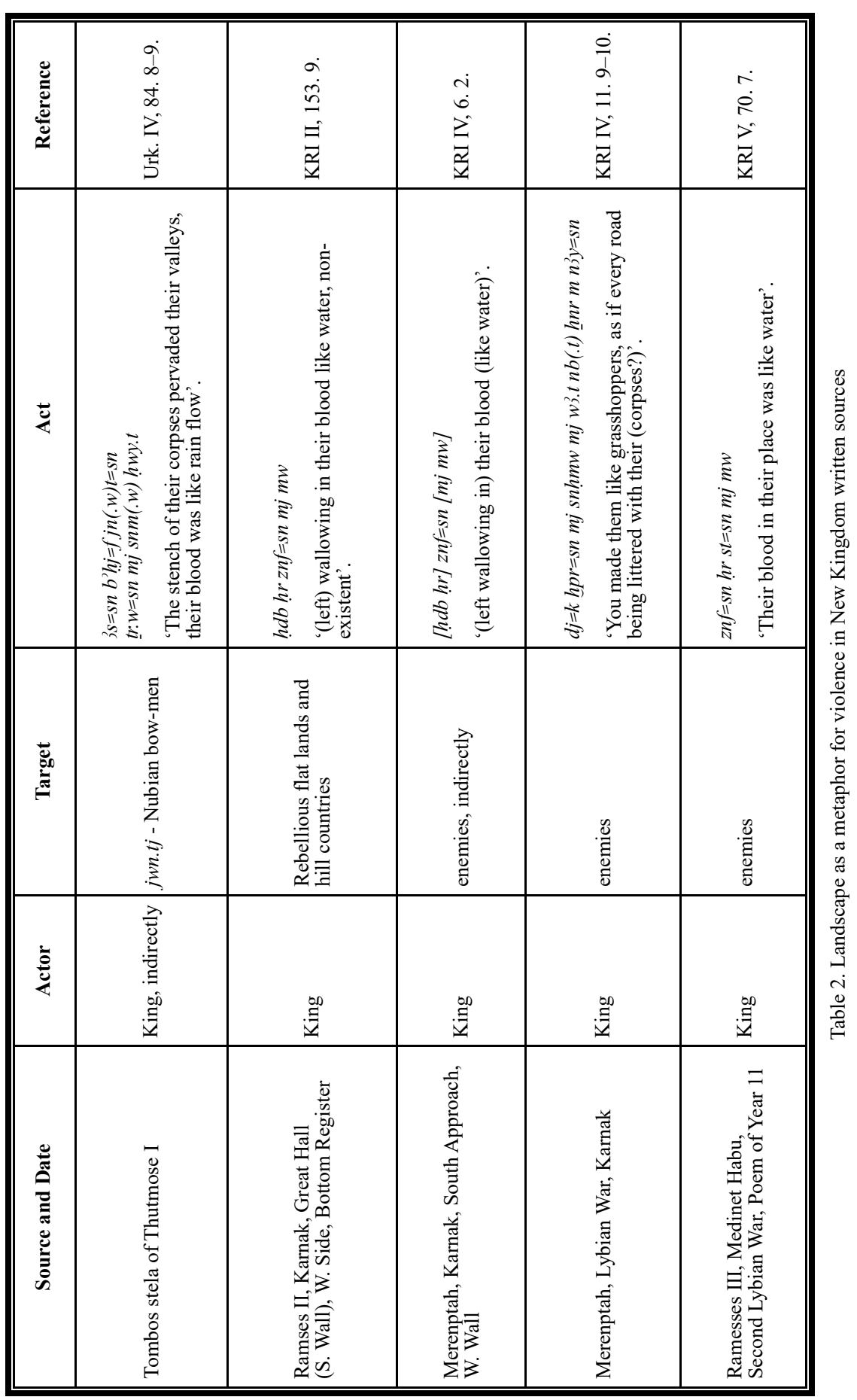




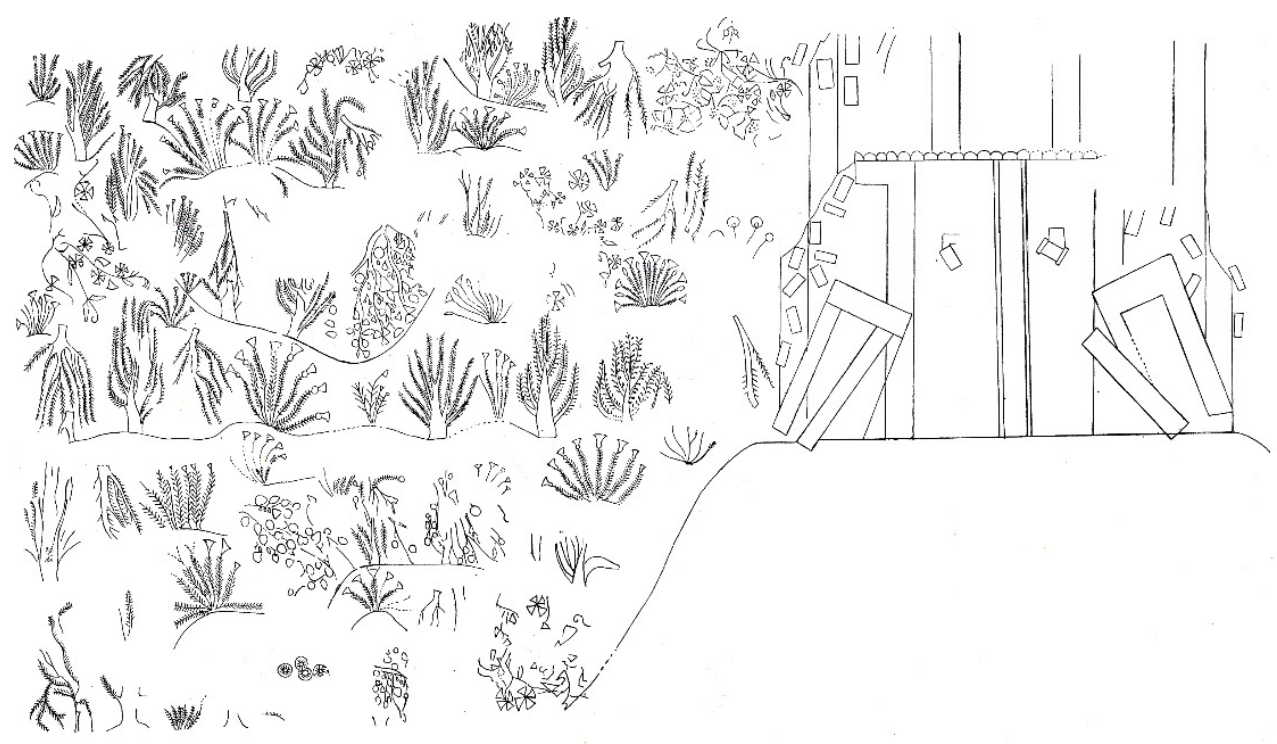

Fig. 1. Desolated city, Ramesses II, Luxor-West Side, Colonnade, West wall, outside, first scene from the north, drawing, detail. ${ }^{30}$

\footnotetext{
${ }^{30}$ Redrawn after Wreszinski 1935: Tf. 65.
} 


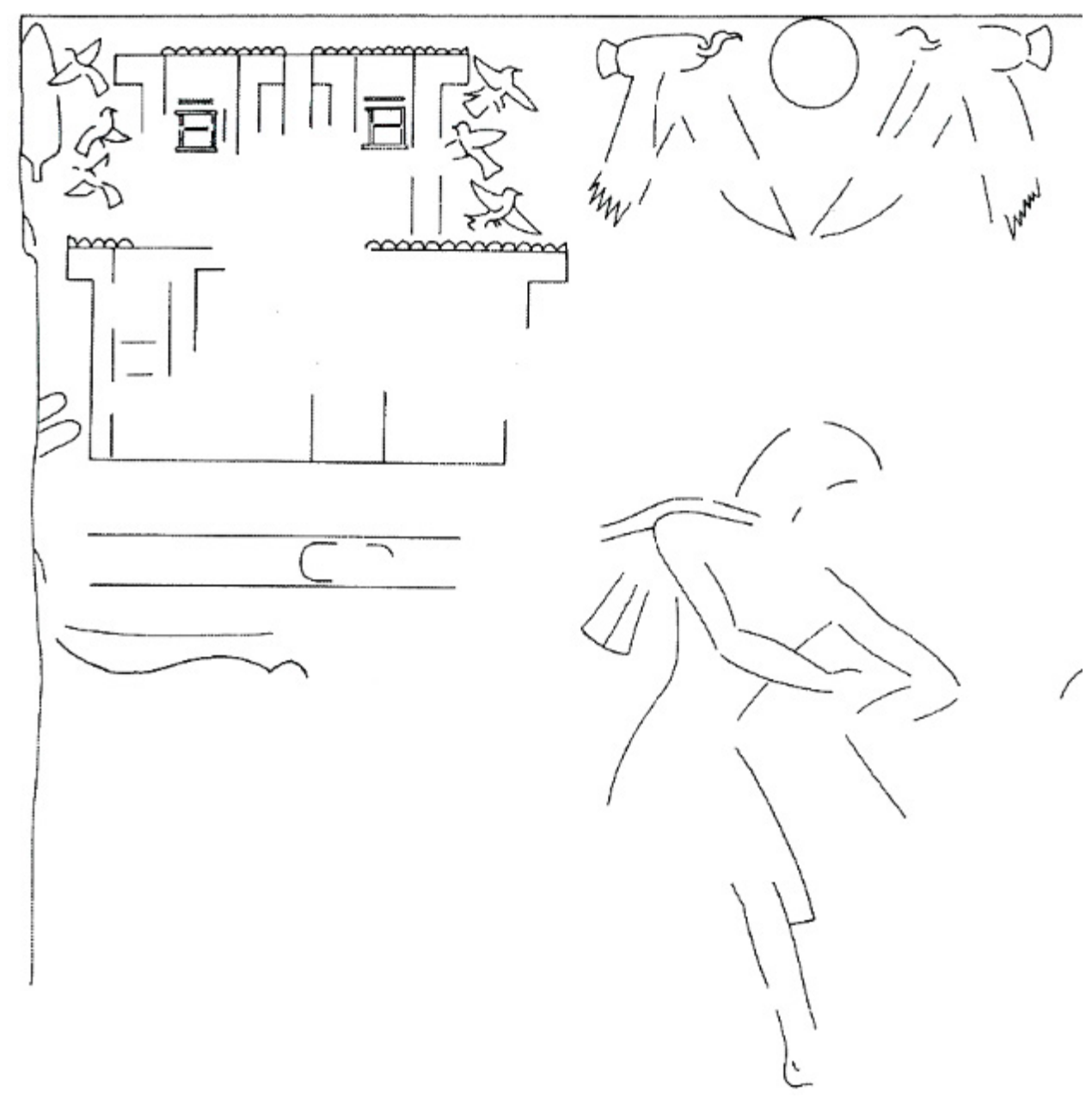

Fig. 2. Desolated city, Ramesses II, Luxor-East, $1^{\text {st }}$ Court, East wall, outside, south of the first pylon, lower register, third scene from the north, drawing, detail. ${ }^{31}$

\footnotetext{
${ }^{31}$ Redrawn after Heinz 2001: 272.
} 


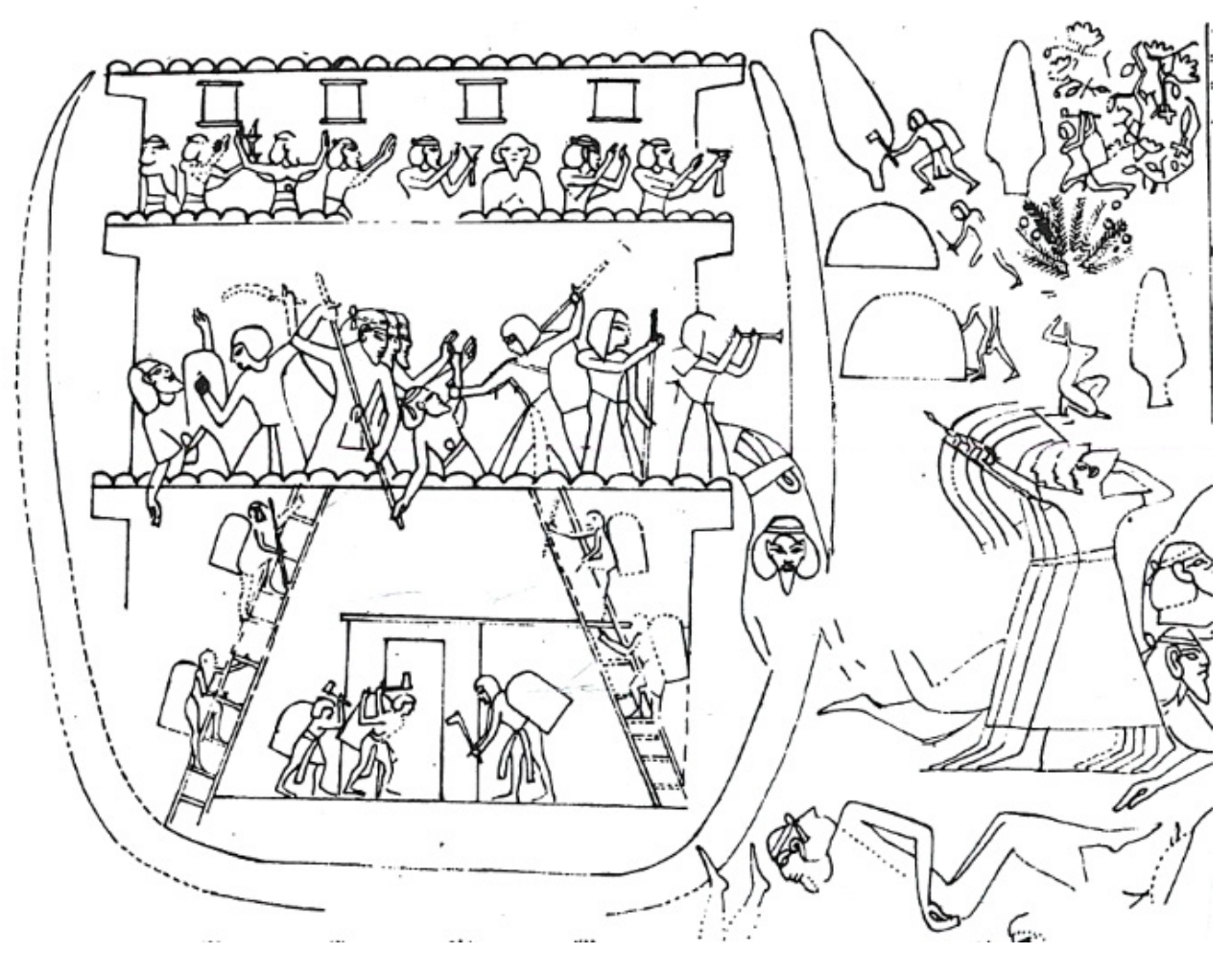

Fig. 3. Siege of Tunip, Ramesses III, Medinet Habu, North wall between the $1^{\text {st }}$ and $2^{\text {nd }}$ pylons, outside, upper register, first scene from the east, drawing, detail. ${ }^{32}$

Since theoretical and methodological approaches to violence in humanities are numerous, some authors suggested concentrating first and foremost on actors and victims of violence. ${ }^{33}$ Some contemporary philosophers consider that violence with an identifiable actor is 'subjective' violence and represents only the tip of the iceberg with 'objective' violence being more problematic because it consists of symbolic and structural violence. ${ }^{34}$ Thus, when analysing attestations of violence in relation to foreign landscapes I first distinguish the subject (e.g. king, soldiers) and object of violence (various landscape elements) and the action involved (various verbs and phrases used to express these actions). This then allows establishing the patterns within the decorum thus opening the possibilities for discussion of certain aspects of 'objective' violence.

\footnotetext{
${ }^{32}$ Redrawn after Wreszinski 1935: Tf. 151.

${ }^{33}$ Schröder, Schmidt 2001.

34 Žižek 2008: 9-11.
} 


\section{Results}

The results of this study are presented in two tables, which are organised according to the context, date, actor, targets in landscape and the act itself. Table 1 represents the sources with attestations of violent acts committed to landscape and Table 2 represents the sources with attestations of landscape as a metaphor for the results of the violent acts.

The results of this study showed that the destruction of enemy landscape is mainly attested in written sources with very few known visual attestations. The main actor in textual attestations is in almost all cases the king and not the army ${ }^{35}$ (cf. Table1), whereas the main actors in visual attestations are the soldiers (Fig. 3). This is clearly a consequence of decorum as in reality such acts were committed by soldiers regardless of the fact that they were ascribed to the king. The large-scale figure of the king is usually placed on the side of the battle and not directly confronting his enemies. If a king is depicted actively engaging in the battle he only targets either the largest figures representing enemy leaders or entire fortresses. ${ }^{36}$

There are various violent acts which are committed against foreign landscapes and their elements in New Kingdom written sources (Table 1). All foreign lands (his.wt nb.wt), the entire earth-lands $(t 3 . w)^{37}$, districts/regions $(w w)^{38}$, towns $(d m j . w)^{39}$, settlements/villages $(w h . w t)^{40}$ and town/city $(n . t)^{41}$ are either destroyed $\left(s k s k / s k^{42}, h b 3\right)$, plundered $(f h)$, or burned ( $r \underline{d}$ j $s \underline{d} . t, w b d, 3 f r)$. The grain $(h . w t)$, barley/grain $(j t)^{43}$, trees/plantations $\left(m n . w^{44}\right)$ and fruit trees $(\text { bnr.w })^{45}$ are cut off $\left.\left(\breve{s}^{3} d^{46}, w h\right)^{37}\right)$.

The trees depicted cut off by Egyptian soldiers in the siege of Tunip of Ramesses III (Fig. 3) have the form of the sign M1 , which is used to determine the lexeme mn.w plantations. ${ }^{48}$ This is a pictorial representation of the phrase attested in the texts (Tab. 1).

The depiction of a desolated enemy fortress destroyed by Ramesses II, depicted on the Luxor temple with destroyed gates and windows and cut down vegetation around it (Fig. 1) stands for complete destruction. ${ }^{49}$ Many of the plants depicted here look like the Egyptian New Kingdom representation of the Egyptian willow (Salix subserrata) from the tomb of Ipj from $19^{\text {th }}$ dynasty Deir el-Medinah. This tree was known in Egypt since the Early

\footnotetext{
${ }^{35}$ This was also argued in general for royal accounts of military events from the reign of Thutmose II to the reign of Merenptah, Lundh 2002, 21.

${ }^{36}$ Heinz 2001; Spalinger 2011: 43-53.

${ }^{37} \mathrm{~Wb} 5,219.12-221.12$.

${ }^{38} \mathrm{~Wb} 1,289$.

${ }^{39}$ Also attested with the meaning quarter of a town, landing place, wharf, Wb 5, 455.5-456.7.

${ }^{40} \mathrm{~Wb} 1,346.12-14$.

${ }^{41} \mathrm{~Wb} 2,210.6-212.4$.

${ }^{42} \mathrm{~Wb} 4,310.7$

${ }^{43} \mathrm{~Wb} 1,142.10-20$.

${ }^{44} \mathrm{~Wb} 2,71.13-16$; For lexical comments see Aufrère 2005: 52-53.

${ }^{45}$ Originating from the word "sweet", Wb 1, 462.7-463.18.

${ }^{46} \mathrm{~Wb} 4,422.3-17$; For lexical comments see Ibid.: 52.

${ }^{47} \mathrm{~Wb} 1,346.15-347.5$.

${ }^{48} \mathrm{~Wb} 2$, 71.13-16; Aufrère 2005: 53-54.

${ }^{49}$ Partridge 2002: 146.
} 
Dynastic Period and is attested as a garden plant. ${ }^{50}$ Few of the plants resemble some of the plants from the well known representation of the so-called "Botanical garden of Thutmose III" located on the walls of the room next to the Festival Hall of Thutmose III, in the Precinct of Amun-Re, Karnak. The plant in question is identified as common grape vine (vitis vinifera) ${ }^{51}$ Considering the diversity of depicted trees and plants which also include flowers, and the above suggested identification of some of them, one could consider that we are dealing with a representation of a garden. The line on the Second stela of Kamose in which Kamose states that he will drink wine from the vineyard of Apophis and cut down his trees, immediately comes to mind. ${ }^{52}$

The depiction of a desolated enemy fortress in the lower register of the third scene from the north on the east outside wall, south of the first pylon of the first court of LuxorEast, with birds flying up and away from the city, is a unique representation (Fig. 2). It can be interpreted as a metaphor of victory and overwhelming success. ${ }^{53}$ There are six birds, three on each side of the fortress, and they can be interpreted as pigeons or pintail ducks. Therefore, it was already suggested that they are related to the letting of the birds as the four sons of Horus during the festival of god Min in order to spread the news of the victory of Horus over the forces of chaos. ${ }^{54}$ The texts in which this is attested are known from the temple walls of Ramesseum of Ramesses II, Medinet Habu of Ramesses III and Karnak of Ramesses III and they are part of the representation in which the priests let the birds go in front of the king. ${ }^{55}$ However, although the depicted birds highly resemble the hieroglyphic sign G40 os "pintail duck" and those birds being let out by the priests during the festival of Min, their number is larger, namely six and not four. Nevertheless, since the king is depicted binding enemies just to the right of this desolated fortress with fleeing birds, the suggested relation to Horus is possible because the king was conceptualised as living Horus on the battlefield. ${ }^{56}$ In her analysis of the Painted Box of Tutankhamun, Regine Schulz showed the importance of numbers in interpreting representations of war. She understands number six as a symbol of royal dualism in various aspects. ${ }^{57}$ The importance of numbers in the New Kingdom Egyptian religious frame of war was also recently emphasized by myself. ${ }^{58}$ However, if we accept the interpretation of number six as a symbol of royal dualism in various aspects in relation to the six birds fleeing from the fortress, it is not clear how royal dualism is related to the king's victory in this particular context. It is maybe more fruitful to interpret the fleeing of the birds as a representation of abandonment and desertion, a "spectacle of desolation", ${ }^{59}$ a result of the king's action. ${ }^{60}$ Such actions of the king are also

\footnotetext{
${ }^{50}$ Germer 1985: 16-17.

${ }^{51}$ Beaux 1990: P1. LVI.

${ }^{52}$ Habachi 1972: 36.

${ }^{53}$ Spalinger 2011: 65.

${ }^{54}$ Keel 1990: 626.

${ }^{55}$ Keel 1977: 113-114.

${ }^{56}$ Müller 2013.

${ }^{57}$ Schulz 2000: 251.

${ }^{58}$ Matić 2017a: 323.

${ }^{59}$ Aufrère 2005: 54.

${ }^{60}$ Müller 2009: 231-232.
} 
textually attested under the phrase "reducing to deserted mounds $(j 3 . w t ~ d \check{s} r . t) " .{ }^{61}$ Mounds (tells) are in New Kingdom Egyptian cultural geography specifically Syro-Palestinian landscape element in iconography starting from the $19^{\text {th }}$ dynasty. ${ }^{62}$

The difference in the treatment of northern and southern enemies in the decorum extensively discussed by Spalinger ${ }^{63}$ can also be found in the sources with attestations of landscape destruction. There seems to be a difference in the treatment between northern and southern landscapes, at least when their visual attestations are concerned. Namely, although Egyptians soldiers are depicted cutting off the trees in the north (Fig. 3), and desolated landscapes are depicted as an aftermath of the battles with the Egyptians (Figs. 1, 2), we do not have parallels for this in the representations depicting battles in Nubia. Nubian landscapes are depicted as closely related to domestic activities of women and children welcoming fleeing and injured Nubian soldiers (Figs. 4, 5). Gaballa A. Gaballa identifies the trees depicted in the Nubian village in the battle scene from Beit el Wali (Fig. 5) as dôm trees ${ }^{64}$. On a closer look one recognizes a monkey in the tree depicted just to the right of a Nubian woman shown in her domestic activities. When compared to the depictions of other enemy landscapes, that of Nubia indeed reflects an idea of landscape without forts or towns. The depiction of Nubian herdsmen and their flock to which the fleeing and injured Nubian soldiers return in the battle in Nubia represented in Derr/West temple could maybe reflect an ancient Egyptian idea of nomadism as designating a non-Egyptian way of life. ${ }^{65}$ Spalinger suggested that the intent behind rather rural representation of Nubian landscape was to depict Nubians as 'not worthy of recognition as civilized people'. ${ }^{66}$ Indeed, as he suggested the fall of Nubia to Egyptian hands was surely partly thanks to advanced military technology of Egypt. ${ }^{67}$ It was also recently suggested that such depictions of Nubians are related to gendered frame of war in New Kingdom Egypt in which enemy men are feminised. ${ }^{68}$ This reversed gendering of the Nubians is clearly related to their representation as cowards. ${ }^{69}$ The Nubian landscape is depicted filled with domestic life and activity of women or the herdsmen with their flock to which the fleeing Nubian men are coming.

\footnotetext{
${ }^{61}$ KRI IV, 20. 15;

${ }^{62}$ Ahrens 2016: 31.

${ }^{63}$ Spalinger 2011: 43.

${ }^{64}$ Gaballa 1976: 112.

${ }^{65}$ Fischer-Elfert 2005: 344-345.

${ }^{66}$ Spalinger 2011: 28.

${ }^{67}$ Spalinger 2005: 62; cf. Spalinger 2011: 43.

${ }^{68}$ Matić 2017b.

${ }^{69}$ Spalinger 2011: 34, 45.
} 


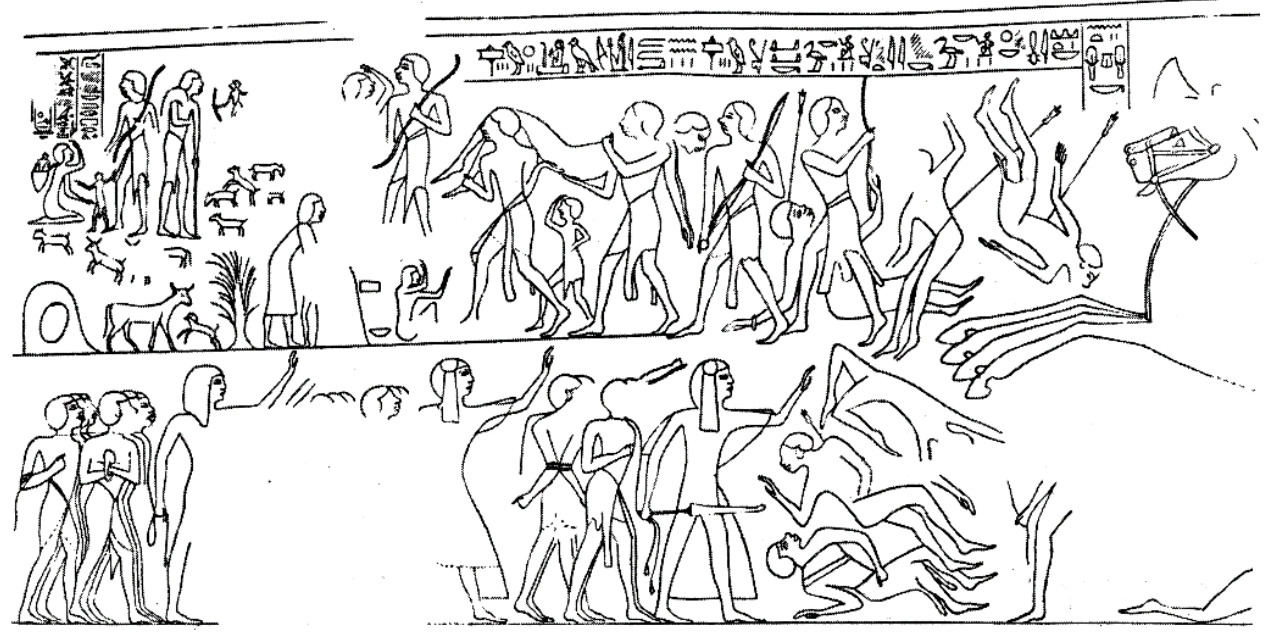

Fig. 4. Nubian campaign, Ramesses II, Derr/West, First columned hall, west wall, lower register, first scene from the south, drawing, detail. ${ }^{70}$

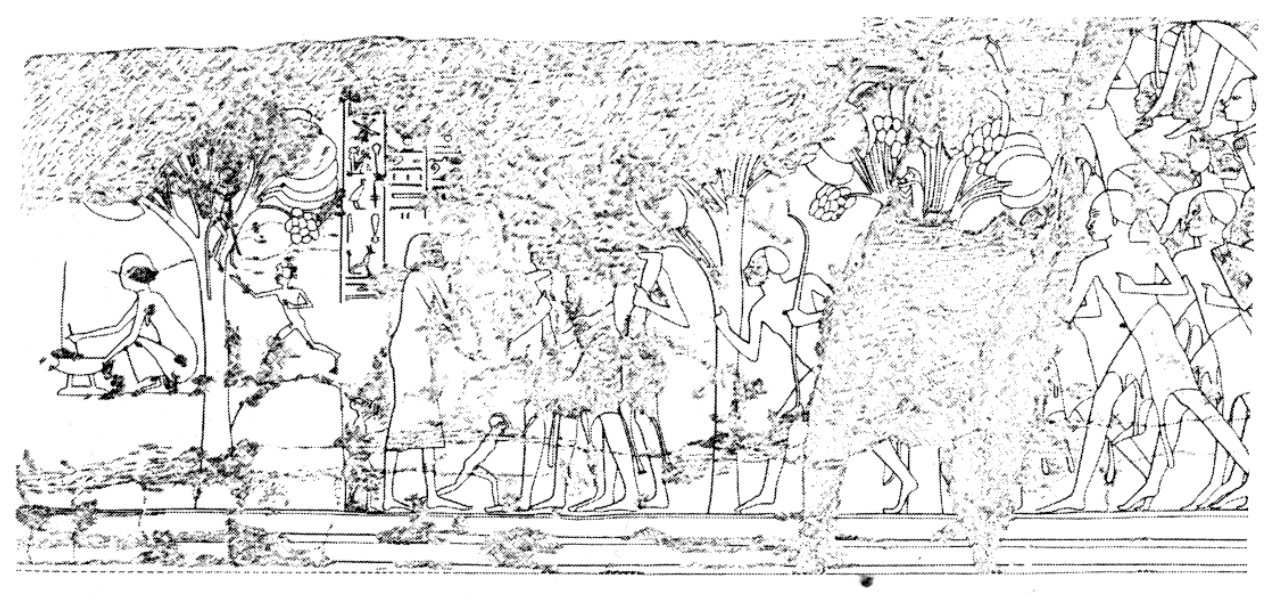

Fig. 5. Nubian campaign, Ramesses II, Beit el Wali/South; Forecourt, South wall, eastern half, drawing, detail. ${ }^{71}$

\footnotetext{
${ }^{70}$ Redrawn after Wreszinski 1935: Tf. 168a.

${ }^{71}$ Redrawn after Wreszinski 1935: Tf. 165f.
} 
This difference in the treatment of Syro-Palestinian and Nubian landscape in Egyptian written and visual representations of war can also be related not only to the difference in landscapes themselves but also consequently to the way the battles were fought. The destruction of grain, barley, fruit trees and plantations attested in the texts and the destruction of trees in front of the Syrian fortresses attested visually can be related to the strategy of cutting the enemy off from their own supplies and the use of these supplies by the Egyptian army which became self-sustaining during the campaigns of Thutmose III. ${ }^{72}$ In military terminology the destruction of enemy fields is known as the scorched earth strategy. ${ }^{73}$ Orchards and other trees were and still are important for the people living in Egypt, Near and the Middle East because they provide greenery, offering shelter from the sun to people and flocks, and are thus a symbol of settled life and places of retreat. ${ }^{74}$ One should also consider that the effects of war on agriculture can be severe and have devastating consequences which can set in motion different social problems. ${ }^{75}$ Nevertheless, the backbone of effective devastation was not the destruction of fruit trees but of wheat and barley ${ }^{76}$ as also attested in the New Kingdom Egypt (Table 1). Destroying orchards and trees also symbolically means destroying the settled life and places of retreat of the enemies. But destroying wheat and barley means cutting the enemy off from their resources and causing devastating effects for the local economy. Thus, it can be suggested that by depicting the destruction of enemy landscape associated to forts in Syria-Palestine there was an attempt to symbolically render these enemies to the level of Libyans, Shasu and Nubians, whose main characteristic, attributed to them by the ancient Egyptians, was unsettled life. It is possible that the fact that there are a small number of these representations actually indicates that scorched earth was not a regular practice as it would be unwise to destroy the resources which could be exploited later either through taxation or expropriation. ${ }^{77}$ Clearly there were no local forts in Nubia comparable to the ones in Syria-Palestine and therefore there was no need for deterious effects on the local community through the destruction of crops and orchards.

However, these observed real differences in northern and southern landscapes could have served in strengthening the already existing value judgments and stereotyped images of the Other which are themselves based on Egyptocentric frame of reference. These should not be confused with value neutral and universal facts and then be interpreted as evidence for stages on cultural evolution. One should stress that the term rmt as a non-ethnic demarcation was not reserved solely for the Egyptians. ${ }^{78}$ This does not exclude the specific alterity of the non-Egyptian rmt. ${ }^{79}$

That landscape is an important element in the construction of Otherness is very well exemplified with the description of Syro-Palestinian landscape in Papyrus Anastasi I. Here

\footnotetext{
${ }^{72}$ Cf. Redford 2003: 195-198; Spalinger 2005: 34-36.

${ }^{73}$ Clausen 1945: 298-299.

${ }^{74}$ Cole 1997: 29.

${ }^{75}$ Hanson 1998: 247-249.

${ }^{76}$ Thorne 2001: 253.

${ }^{77}$ Cf. Cole 1997: 29.

${ }^{78}$ Moers 2005.

${ }^{79}$ Spalinger 2011: 209.
} 
it is written that a narrow path is dangerous because of the "Bedouins" hiding under the bushes. These men are described as four or five cubits tall. The path is overgrown with reeds and brambles. ${ }^{80}$ A possible visual parallel to Asiatics hiding in the bushes is the representation of the siege of Jenoam of Sethi I which is found in the first scene from the east in the middle register on the outer north wall east of the entrance to the hypostyle of the Karnak temple. Here just under the representation of the fort of Jenoam under siege there are trees among which one can see hidden Asiatics. ${ }^{81}$ Unlike in the Papyus Anastasi I, these hiding Asiatics are everything but scary.

Finally, the representations of both northern and southern landscapes share a common denominator of the "desert", an uninhabitable, dangerous, threatening landscape from the elite Egyptian point of view ${ }^{82}$ and a place dictating nomadism and the lack of permanent residence, ${ }^{83}$ a landscape in which the elite and the king hunt. ${ }^{84}$ There are well known parallels between war and hunting in ancient Egypt observable, for example, in patterns of representation where both the hunter and the king, sometimes even in the same figure, storm into a mass of hunted animals or enemies.

\section{Discussion}

Landscape is an important element of expression of victory in New Kingdom Egyptian texts, especially in the description of the outcomes of the conflicts with enemies (Table 2). Thus, in the text of the Tombos stela of Thutmose I it is written that the "stench of enemy corpses pervaded their valleys and their blood was like rain flow" (3s=sn $b^{\prime} h j=f$ $j n(. w) t=s n t r w=s n m j \operatorname{snm}(. w) h w y . t)$, clearly referring to the quantity of the fallen enemies. These quantitative metaphors are achieved also through comparing bodily fluids of enemies with the elements of landscape, since in the texts of Ramesses II from the Great Hall at Karnak and of Merenptah from South Approach at Karnak enemies are described as "(left) wallowing in their blood like water" ( $h d b h r z n f=s n m j m w)$. Also, in the text of the Second Libyan War, the Poem of Year 11 of Ramesses III at Medinet Habu it is written that "their blood in their place was like water" (znf=sn $h r s t=s n m j m w)$. The conceptualizations of landscape as body parts were indeed not foreign to ancient Egyptians. ${ }^{85}$ What is interesting is that the body parts and fluids of enemies (e.g. blood) can also be conceptualized like elements of landscape and nature in specific contexts. Therefore the elements of landscapes can be hurt in the same way as bodies can, which explains the lexical choice in preserved attestations (Table 1). Namely, the verbs used to describe the violent actions against foreign landscape, "to destroy" ( $s k s k / s k, \underline{h b}$ ) ) or "to burn" ( $r \underline{d} j \underline{j} \underline{d} . t, w b d, 3 f r)$ are, for example, well attested as targeting bodies of the damned dead in the Underworld or enemies in battle.

The enemies are in the text of the Lybian War of Merenptah at Karnak compared to

\footnotetext{
${ }^{80}$ Moers 2010: 174.

${ }^{81}$ Wreszinski 1935: Tf. 36.

${ }^{82}$ Baines 2013: 37-38.

${ }^{83}$ Fischer-Elfert 2005: 332; Spalinger 2011: 209.

${ }^{84}$ Baines 2013: 223-224.

${ }^{85}$ Wattler 2016.
} 
insects and it is written in relation to the king: "You made them like grasshoppers, as if

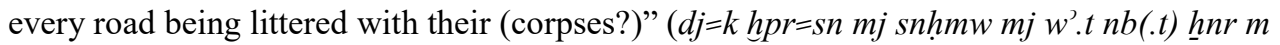
$n 3 y=s n$ ). This again indicates the number of defeated enemies expressed via the image of the swarm of grasshoppers on the roads. Indeed, grasshoppers are a known topos of a pest in the Near East because of their ability to bring disaster and destroy crops. ${ }^{86}$

The destruction of elements of landscape is a military practice and an element of representations of war also in neighbouring Near Eastern states. Marian Feldman even suggested that the Assyrian representations of war were based on the Egyptian model. Assyrian soldiers under Ashurnasirpal II, Šalmaneser III, Tiglath-Pileser III and Senacherib are like Egyptian soldiers under Ramesses III depicted cutting down trees. ${ }^{87}$ However, it would be an overstatement to say that the motif of landscape destruction in Assyria originates from Egypt. This is because the number of visual attestations in New Kingdom Egypt is small and the motif of landscape destruction was not among the prominent motifs of the New Kingdom Egyptian visual decorum of war. An additional argument against the New Kingdom Egyptian inspiration is the fact that the motif of landscape destruction is known in the Near East art since at least the first half of the $18^{\text {th }}$ century BCE. ${ }^{88}$ Middle Assyrian kings such as Adad-Nirari I and Šalmaneser I also practiced re-sowing of the destroyed enemy fields with 'salty plants' to prevent the refoundation of enemy cities. ${ }^{89}$ Such practices are not attested in ancient Egyptian military documents or representations of war.

Last but not the least we should attempt to address the issue of the archaeological record in connection to landscape destruction attested both in it and in the written and visual sources discussed so far. Clearly, we cannot easily recognise the actions attested in written and visual sources in the archaeological record. This is nowhere better illustrated than in the case of ancient Avaris (modern Tell el-Daba) where no traces of destruction at the end of the Second Intermediate Period are attested so far although written sources would want us to think so. ${ }^{90}$

However, the fact is that only with the reign of Thutmose III it is possible to associate some of the destructions in Canaan with Egyptian campaigns, either as plundering or as sieges. ${ }^{91}$ According to Hasel the references to fiery powers of the king in burning enemies and their cities could have some historical validity as an Egyptian military tactic inflicted by the king or military upon the enemies. Nevertheless, he argues that it is still more likely that we are dealing here with stereotypical rhetoric. ${ }^{92}$ This is indeed confirmed by the generic choice of victims and objects of such an action like burning. But we should therefore not be hasty in entirely dismissing written and visual attestations because archaeological record does indicate that sites were indeed destroyed. After all, once stripped of sedimented

\footnotetext{
${ }^{86}$ Borowski 2001: 303; Hoffmeier 1997: 148; Rivnay 1962: 19. For bound enemies depicted in the form of grasshopers see Hsu 2017.

${ }^{87}$ Cole 1997: Figs. 1-8.

${ }^{88}$ Ibid.: 31.

${ }^{89}$ Richardson 2015: 42.

${ }^{90}$ Bietak, Dorner und Jánosi 2001: 38; Bader 2013: 265.

${ }^{91}$ Burke 2010: 53-54.

${ }^{92}$ Hasel 1998: 85.
} 
meanings landscape becomes a surface like any other, open for exploitation. ${ }^{93}$ Thus, although there is nothing suggesting that exploitation and sometimes destruction of foreign landscape never happened, this still does not answer the questions how "true" the textual and visual representations of these actions are. This is indeed a hard question to answer. Actions such as cutting down or burning vegetation (grain, barley, fruit trees) do not leave archaeological traces which are easily noticeable and it would be hard to differentiate between different causes of destruction based on the archaeological record alone. Additionally, from the logistic point of view crops were important for the mustering Egyptian soldiers and it is highly probable that military campaigns were planned according to the harvest seasons. ${ }^{94}$ Thus, even if well equipped, additional supplies in food are more than welcomed on a military campaign and the destruction of crops would impede them. Therefore, as Spalinger already suggested, it is possible that when records inform us on towns being taken and their grain and fruits being cut down, we are indeed dealing with additional supplies for the Egyptian army. ${ }^{95}$ The only context in which deliberate destruction of enemy crops has its advantage is a siege of an enemy fort when scorched earth strategy can be used to starve the inhabitants. Although there were probably cases in which this was done, one should be careful in interpreting every attestation of crops destruction as evidence for starving the enemy. Indeed, if one looks closer the attestations at hand, they seem to be rhetoric (Tab. 1). Also, as already stated, the destruction of cities in Canaan can be archaeologically documented, but is not always easy to interpret it as caused by Egyptian sieges. ${ }^{96}$ Following Parkinson, concentrating on experience rather than on the problematic binary dichotomy of "actual" vs. "imaginary" we can move closer to what he terms "the rules of the game" and what is implied by these representations. ${ }^{97}$

We should therefore ask how and under which rules of decorum and frames of war these destructions of landscape are represented. I refer to the decorum following the definition of John Baines as "a set of rules and practices, defining what may be represented, pictorially with captions, displayed and possibly written down, in which context and in what form $[\ldots]$ and was probably based ultimately on rules and practices of conduct and etiquette, of spatial separation and religious avoidance". ${ }^{98}$ With the term "frames of war" I refer to what Judith Butler describes as the ways of selectively carving up experience as essential to the conduct of war having normative functions, and thus to the selective and differential framing of violence. ${ }^{99}$ As I have stated previously the actor is in almost all written attestations of landscape destruction no one other than the king. This fact goes in line with the depictions of the king in battle representations as "superhuman" and with his direct engagements only with enemy leaders or entire fortresses. ${ }^{100}$ This is understandable as, after

\footnotetext{
93 Tilley 1994: 21.

${ }^{94}$ Spalinger 2005: 85 .

${ }^{95}$ Spalinger 2005: 132.

${ }^{96}$ Burke 2010: 53-54.

${ }^{97}$ Parkinson 2015: 14. Cf. Ahrens 2016.

${ }^{98}$ Baines 1990: 20.

${ }^{99}$ Butler 2009.

${ }^{100}$ Spalinger 2011: 43-53.
} 
all, the king is no human ${ }^{101}$ and he comes out accordingly through the decorum. Engagement with grain, barley, fruit trees and plantations is in visual attestations reserved for the soldiers who are depicted cutting down trees (Fig. 3) and from the point of view of decorum such mundane actions in war are something which is left to soldiers. Indeed, this is where we can also speak about the reality of war. That violence against enemies was framed in the terms of landscape is indicated by the use of landscape metaphors such as rain flow in valleys or water for blood. The aim was clearly to indicate the gravity of Egyptian victory and the loss the enemies had. The roads of enemies are also described as being littered with their corpses like grasshoppers indicating the share number of the killed but also relating landscape frame of war with other frames of war such as dehumanisation. ${ }^{102}$ At the same time by representing destroyed elements of enemy landscapes these landscape are being represented as uninhabitable, deserted and non-Egyptian.

\section{Conclusion}

Wars ancient Egyptians waged against foreign countries apart from bringing death and destruction to the people are represented in decorum as also bringing destruction to foreign lands. There are written attestations of this in Old and Middle Kingdom, but also the Second Intermediate Period, however a larger number of attestations dates to the New Kingdom when the destruction of enemy landscape is also visually represented. The earliest written source for this practice dates to the reign of Thutmose I and the latest to the reign of Ramesses III, whereas the visual attestations are so far known only from the times of Ramesses II and Ramesses III.

Landscape destruction is targeting foreign lands, districts, plains, hill countries, cities, towns, settlements, villages, specific toponyms, but also plantations, grain, barley and fruit trees. It seems that Syro-Palestinian landscapes are the targets of violence in visual attestations, whereas Nubian landscapes are targeted only in textual attestations which are quite often rhetorical. This pattern can be related to the reality of war which was different in these two regions. However, it could have also functioned as a visual symbolism of reduction of urban Syro-Palestinian landscapes to unsettled landscapes ancient Egyptians attributed to their other enemies such as Libyans, Shasu and Nubians.

The actor behind the destruction of landscape is the king in almost all written attestations. The actors in cutting of the trees around enemy fortresses in visual representations are soldiers. This division in the decorum is clearly related to the difference in status, but also ontology, like when the king is depicted engaging with the enemies directly then he either defeats the leading enemy figures or entire fortresses, as a 'superhuman' or indeed a 'nonhuman' does.

Metaphors using landscape elements such as rain flow and water for blood, or roads filled with grasshoppers for dead bodies of enemies, are used to indicate the gravity of the defeat. Thus, landscape is described as body and as much as bodies can be hurt so can landscape be hurt too.

\footnotetext{
${ }^{101}$ Quack 2010: 1.

${ }^{102}$ Cf. Hsu 2013: 10-12.
} 


\section{REFERENCES:}

Ahrens, A. 'Zur Bedeutung und Funktion von Tellstrukturen in den Feldzugsdarstellungen des Neuen Reiches'. Göttinger Miszellen, 248, 2016, 27-38.

Aufrère, S. J. 'La destruction des arbres et des cultures des villes à l'occasion d'un siege', in: S. H. Aufrère (éd.), Encyclopédie religieuse de l'Univers végétal. Croyances phytoreligieuses de l'Égypte ancienne Volume III, Orientalia Monspeliensia XV, Montpellier: Université Paul Valéry, 2005, 49-57.

Bader, B. 'Cultural Mixing in Egyptian Archaeology: The 'Hyksos' as a Case Study', in: W. P van Pelt (ed.), Archaeology and Cultural Mixture. Archaeological Review from Cambridge 28.1. Cambridge: Archaeological Review from Cambridge, 2013, 257-286.

Baines, J. 'Restricted Knowledge, Hierarchy, and Decorum: Modern Perceptions and Ancient Institutions', Journal of American Research Centre in Egypt, XXVII, 1990, 1-23.

. High Culture and Experience in Ancient Egypt. Sheffield and Bristol: Equinox, 2013.

Beaux, N. Le cabinet de curiosités de Thoutmosis III. Plantes et animaux du «Jardin botanique» de Karnak. Orientalia Lovaniensia Analecta 36. Leuven: Uitgeverij Peeters, 1990.

Bietak, M., Dorner, J., und Jánosi, P. “Ausgrabungen in dem Palastbezirk von Avaris. Vorbericht Tell el-Dabca/cEzbet Helmi 1993-2000,” Ägypten und Levante XI, 2001, 27-119.

Burke, A. A. 'Canaan under Siege. The History and Archaeology of Egypt's War in Canaan during the Early Eighteenth Dynasty', in: J. Vidal (ed.), Studies on War in the Ancient Near East. Collected Essays on Military History, Altes Orient und Altes Testament 372, Münster: Ugarit Verlag, 2010, 43-66.

Borowski, O. 'Animals in the Literatures of Syria-Palestine', in: B. J. Collins (ed.), A History of the Animal World in the Ancient Near East, Handbook of Oriental Studies 64, Leiden: Brill, 2001, 289-306

Butler, J. Frames of War. When is Life Grievable?, London: Verso, 2009

Clausen, W. 'The Scorched Earth Policy, Ancient and Modern',The Classical Journal, 40 (5), 1945, 298-299.

Cole, S. W. 'The Destruction of Orchards in Assyrian Warfare', in: S. Parpola and R. M. Whiting (eds.), Proceedings of the 10th Anniversary Symposium of the Neo-Assyrian Text Corpus Project Helsinki, September 7-11, 1995, Helsinki: The Neo-Assyrian Text Corpus Project, 1997, 2940.

Erman, A. und Grapow, H. Wörterbuch der ägyptischen Sprache, Band I-V, Berlin: Akademie Verlag, $1926=\mathrm{Wb}$.

Feldman, M. 'Nineveh to Thebes and Back: Art and Politics between Assyria and Egypt in the Seventh Century BCE', Iraq 66, 2004, 141-50.

Fischer-Elfert, H. W. 'Sedentarism and Nomadism as Criteria of Ancient Egyptian Cultural Identity', in: S. Leder and B. Streck (eds.), Shifts and Drifts in Nomad-Sedentary Relations. Nomaden und Sesshafte 2, Wiesbaden: Dr. Ludwig Reichert Verlag, 327-350.

Gaballa, A. G. Narative in Egyptian Art. Mainz: Philipp von Zabern, 1976.

Galter, H. D. 'Die Landschaft als Feind. Schlachtfelder in der assyrischen Geschichtsschreibung'. Schield von Steier 27, 2016, 18-27.

Germer, R. Flora des pharaonischen Ägypten. Sonderschriften des Deutschen Archäologischen Institus Abteilung Kairo 14. Mainz am Rhein: Verlag Philipp von Zabern, 1985.

Habachi, L. The Second Stela of Kamose and his Struggle against the Hyksos Ruler and his Capital. Abhandlungen des Deutschen Archäologischen Instituts Kairo Ägyptologische Reihe 8. Glückstadt: Verlag J. J. Augustin, 1972.

Hanson, V. D. Warfare and Agriculture in Classical Greece. Revised Edition, Biblioteca di Studi 
Antichi 40, Berkeley: University of California Press, 1998.

Harvey, S. P. The Cults of King Ahmose at Abydos, University of Pennsylvania, 1998.

Hasel, M. G. Domination and Resistance: Egyptian Military Activity in the Southern Levant, 13001185 BC, Probleme der Ägyptologie XI, Leiden: Koninklijke Brill, 1998.

Heinz, S. C. Die Feldzugdarstellungen des Neuen Reiches. Eine Bildanalyse, Untersuchungen der Zweigstelle Kairo des Österreichsischen Archäologischen Institutes XVII, Wien: Verlag der Österreichischen Akademie der Wissenschaften, 2001.

Helck, H. W. Urkunden der 18. Dynastie. Text der Häfte 17-22. 3 Bde, Urkunden des Aegyptischen Altertums IV, Berlin: Akademie Verlag, 1984=Urk IV.

Hoffmeier, J. K. Israel in Egypt. The Evidence for the Authenticity of the Exodus Tradition, Oxford: Oxford University Press, 1997.

Hsu, S-W. 'Figurative Expressions Referring to Animals in Royal Inscriptions of the 18th Dynasty', Journal of Egyptian History 6, 2013, 1-18.

. 'Captured, Defeated, Tied and Fallen: Images of Enemies in ancient Egypt', Göttinger Miszellen, 252, 2017, 71-87.

Janssen, J. M. 'The Stela (Khartoum Museum No. 3) from Uronarti', Journal of Near Eastern Studies XII 1953: 51-58.

Keel, O. Vögel als Boten. Studien zu Ps 68, 12-14, Gen 8, 6-12, Koh 10, 20 und dem Aussenden von Botenvögeln in Ägypten. Mit einem Beitrag von Urs Winter zu Ps 56,1 und zur Ikonographie der Göttin mit der Taube, Orbis Biblicus et Orientalis 14, Freiburg: Universitätsverlag, 1977.

. 'Eine Festung mit Vögeln', in: S. Israelit-Groll (ed.), Studies in Egyptology presented to Miriam Lichtheim II. Jerusalem: The Magnes Press, 1990, 625-631.

Kitchen, K. Ramesside Inscriptions. Historical and Biographical I, Oxford: Blackwell, 1975=KRI I. . Ramesside Inscriptions. Historical and Biographical II. Oxford: Blackwell, 1979=KRI II Ramesside Inscriptions. Historical and Biographical IV, Oxford: Blackwell, 1982= KRI IV. Ramesside Inscriptions. Historical and Biographical V. Oxford: Blackwell. 1983= KRI V

Krug, E. G., Dahlberg, L. L., Mercy, J. A., Zwi, A. B. and Lozano R. (eds.) World report on violence and health, Geneva: World Health Organisation, 2002.

Lundh, P. Actor and Event. Military Activity in Ancient Egyptian Narrative Texts from Tuthmosis to Merenptah. Uppsala: Akademitryck, 2002.

Manassa, C. Imagining the Past. Historical Fiction in New Kingdom Egypt, Oxford: Oxford University Press, 2013.

Matić, U. 'Enemies Hanged Upside (Head) Down', in: M. Tomorad and J. Popielska-Grzybowska (eds.), Egypt 2015: Perspectives of Research Proceedings of the Seventh European Conference of Egyptologists 2nd-7th June 2015, Zagreb, Croatia, Oxford: Archaeopess, 2017a, 319-327.

. 'Traditionally Unharmed? Women and Children in NK Battle Scenes', in: A. Kahlbacher and E. Priglinger (eds.), Proceedings of the 5th International Congress for Young Egyptologists, Vienna, 15-19 September 2015, Vienna: Austrian Academy of Sciences, 2017b, in press.

Meurer, G. 'Das Motiv der „Verwüstung ausländischen Territoriums“', in Texten des Alten, Mittleren und Neuen Reiches', in: C-B Arnst, I. Hafemann und A. Lohwasser (Hrsg.), Begegnungen. Antike Kulturen im Niltal. Festgabe für Erika Endesfelder, Karl-Heinz Priese, Walter Friedrich Reineke und Steffen Wenig von Schülern und Mitarbeitern, Leipzig: Verlag Helmar Wodtke und Katharina Stegbauer, 2001, 325-347.

Moers, G. 'Auch der Feind war nur ein Mensch. Kursorisches zu einer Teilansicht pharaonischer Selbst- und Fremdwahrnehmungsoperationen', in: H. Felber (Hrsg.) Feinde und Aufrührer Konzepte von Gegnerschaft in ägyptischen Texten besonders des Mittleren Reiches. Abhandlungen der Sächsischen Akademie der Wissenschaften zu Leipzig 78, 5. Stuttgart/Leipzig: S. Hirzel Verlag, 2005, 223-282. 
Moers, G. 'The World and the Geography of Otherness in Pharaonic Egypt', in: K. A. Raaflaub and R. J. A. Talbert (eds.), Geography and Ethnography-Perceptions of the World in Pre-Modern Societies. Oxford: Wiley-Blackwell, 2010, 169-181.

Monnier, F. 'Une iconographie égyptienne de l'architecture défensive'Égypte Nilotique et Méditerranéenne 7, 2014, 173-219.

Müller, M. 'Bildliche Quellen zur Militärgeschichte', in: R. Gundlach und C. Vogel (Hrsg.) Militärgeschichte des pharaonischen Ägypten. Altägypten und seine Nachbarkultur im Spiegel aktueller Forschung, Paderborn: F. Schöning, 2009, 217-242.

. 'Der Lebende Horus auf dem Schlachtfeld',Kemet. Die Zeitschrift für Ägyptenfreunde, 22 (1), 2013, 15-18.

Parkinson, R. B. 'Now, Voyager: a preface on the poetics of place', in: C. Alvarez, A. Belekdanian, A-K Gill and S. Klein (eds.), Current Research in Egyptology 2015. Proceedings of the Sixteenth Annual Symposium University of Oxford 2015, Oxford and Philadelphia: Oxbow Books, 1-19.

Partridge, R. B. Fighting Pharaohs. Weapons and Warfare in Ancient Egypt. Manchester: Peartree Publishing, 2002.

Quack, J. F. 'How unapproachable is a Pharaoh?', in: G. B. Lanfranchi and R. Rollinger (eds.), Concepts of Kingship in Antiquity. Proceedings of the European Science Foundation Exploratory Workshop held in Padova, November $28^{\text {th }}$-December 1 ${ }^{\text {st }}, 2007$, History of Ancient Near East XI, Padova: S.A.R.G.O.N Editrice e Libreria, 2010, 1-14.

Redford, D. B. Wars in Syria and Palestine of Thutmose III. Culture and History of the Ancient Near East 16, Leiden: Brill, 2003.

Richardson, S. 'Insurgency and Terror in Mesopotamia', in: T. Howe (ed.), Brill's Companion to Insurgency and Terrorism in the Ancient Mediterranean. Brill's Companions in Classical Studies Online III, Leiden: Brill, 2015, 29-61.

Rivnay, E. Field Crop Pests in the Near East, Monographiea Biologicae X, Dordrecht: Springer Science, 1962.

Schröder, I.W and Schmidt, B. E. 'Introduction: Violent imaginaries and violent practices', in: I. W. Schröder and B. E. Schmidt (eds.), Anthropology of Violence and Conflict, London: Routledge 2001, 1-24.

Schulz, R. 'Remarks on the Composition of Hunting and Battle Scenes on the Chest of Tutankhamun' In S. Sherratt (ed.) The wall paintings of Thera: proceedings of the first international symposium: Petros M. Nomikos Conference Centre, Thera, Hellas, 30 August-4 September 1997. Volume I, Athens: Thera Foundation, 2000, 247-266.

Sethe, K. H. Urkunden der 18. Dynastie. Text der Häfte 1-16. 4 Bde, Urkunden des Aegyptischen Altertums IV, Berlin-Graz: Akademie Verlag, 1961=Urk IV.

Smith, H. S. The Fortress of Buhen. The Inscriptions. Egypt Exploration Society Excavation Memoir 48. London: Egypt Exploration Society, 1976.

Strudwick, N. C. Texts from the Pyramid Age. Writings from the Ancient World 16. Atlanta: Society for Biblical Literature, 2005.

Spalinger, A. J. Aspects of the Military Documents of the Ancient Egyptians, Yale Near Eastern Researches 9, New Haven: Yale University Press, 1982.

. War in Ancient Egypt. The New Kingdom, Oxford: Blackwell, 2005.

. Icons of Power. A Strategy of Reinterpretation, Prague: Faculty of Arts, Charles University in Prague, 2011.

'Egyptian New Kingdom Triumphs: A First Blush', in: A. J. Spalinger and J. Armstrong (eds.), Rituals of Triumph in the Mediterranean World. Culture \& History of the Ancient Near East 63. Leiden and Boston: Brill, 2013, 95-122. 
Thorne, J. A. 'Warfare and Agriculture: The Economic Impact of Devastation in Classical Greece', Greek, Roman, and Byzantine Studies 42, 2001, 225-253.

Tilley, C. A Phenomenology of Landscape. Places, Paths and Monuments, Oxford: Berg, 1994.

Vogel, C. 'Storming the Gates? Entrance Protection in the Military Architecture of Middle Kingdom Nubia', in: M. Bietak, E. Czerny and I. Forstner-Müller (eds.), Cities and Urbanism in Ancient Egypt. Untersuchungen der Zweigstelle Kairo des Österreichischen Archäologischen Institutes XXXV. Wien: Verlag der Österreichischen Akademie der Wissenschaft, 2010, 299-320.

Wattler, M. 'Menschliche Körperteile in der Architektur und Landschaft des Alten Ägypten', in: S. Beck, B. Backes, I-T. Liao, H. Simon und A. Verbovsek (Hrsg.),Gebauter Raum: Architektur - Landschaft - Mensch. Beiträge des fünften Münchner Arbeitskreises Junge Aegyptologie (MAJA 5) 12.12. bis 14.12.2014, Göttinger Orientforschungen 62, Wiesbaden: Harrassowitz Verlag, 2016, 211-222.

Wreszinski, W. Atlas zur altaegyptischen Kulturgeschichte. Teil II, Leipzig: J. C. Hinrichs, 1935.

Wreszinski, W., Ranke, H. und Burchardt, M. Ägyptische Inschriften aus den Königlichen Museen zu Berlin. Erster Band. Inschriften von der ältesten Zeit bis zum Ende der Hyksoszeit. Leipzig: J. C. Hinrichssche Buchhandlung, 1913.

Žába, Z. The Rock Inscriptions of Lower Nubia (Czechoslovak Concession). Charles University of Prague Czechoslovak Institute of Egyptology in Prague and in Cairo Publications 1. Prague: Charles University of Prague, 1979.

Žižek, S. Violence. Six Sideways Reflections, New York: Picador, 2008.

\section{UROŠ MATIĆ \\ Univerzitet u Minsteru \\ SPALJENA ZEMLJA: NASILJE I PEJZAŽ U SLIKAMA RATA U NOVOM EGIPATSKOM KRALJEVSTVU}

\section{Rezime}

Smrt ljudi i uništenje zemlje su deo stvarnosti rata. Od Starog carstva uništenje neprijateljskog pejzaža je posvedočeno u egipatskim pisanim izvorima, a broj svedočanstava se povećava u narednim periodima i kulminira u Novom carstvu. Ovo je takođe period kada se javljaju prve likovne predstave uništenja neprijateljskog pejzaža. U ovom radu istražujemo učesnike, mete i činove koji se tiču nasilja protiv neprijateljskog pejzaža u kombinaciji sa upotrebom elemenata pejzaža kao metafore za nasilan tretman neprijatelja tokom Novog carstva. Rad pokazuje da postoje razlike u predstavljanju tretmana sirijsko-palestinskog i nubijskog pejzaža, što može da bude povezano sa samim stvarnostima rata, pošto monumentalne neprijateljske tvrđave nisu postojale u Nubiji, bar ne u onom obliku i veličini kao u Siriji-Palestini. Ova stvarna razlika išla je ruku pod ruku sa drevnim egipatskim konstruisanjem Drugog kao nenaseljenog. Stoga, urbani pejzaži Sirije-Palestine su meta nasilja u likovnim predstavama, gde su svedeni na nenaseljene pejzaže zbog uništenja i pustošenja. U radu takođe pokazujemo kako se ova stvarnost rata dodatno uobličuje kroz pravila egipatskog dekoruma, gde se veći deo uništenja pejzaža pripisuje kralju i samo određen deo vojnicima.

Ključne reči: nasilje, rat, pejzaž, Novo carstvo, Egipat, Sirija-Palestina, Nubija. 